\title{
Currents of Revolution: The Cuban Revolution's Impact on the US News Media Industry, US Spanish-Language Media, and Latina/o Consumption
}

\begin{abstract}
This article explores how the US news media was impacted by events in mid-twentieth century Cuba, namely, the 1959 Revolution and the demise of Havana as a Latin American media capital. This study argues that the Cuban Revolution and its exiles influenced the US news media industry in three significant ways: 1) propelled the expansion of US Spanish-language media, particularly the news, by incorporating Cuban media professionals and serving immigrant audiences from Cuba and later other Latin American nations; 2) removed and limited programs that angered the Cuban community by accommodating Cuban exile activists; and 3) dramatically increased coverage of Cuba and its refugees with an often anti-revolution position. By weaving together primary source materials and scholarly literature, this study reverses the conceptual direction of influence from the US shaping the Caribbean to the Caribbean's impact on the US for a fuller picture of their transnational exchanges.
\end{abstract}

\section{Keywords}

media industry, Cuban Revolution, Cuban diaspora, news broadcasting, transnational journalism

Scholars of the Caribbean and broadcast media have complicated oft-simplified notions of media imperialism by accounting for local and transnational forces while also not losing sight of the neo-colonial relationship between the Caribbean and the US. ${ }^{1}$ While we know the myriad of ways in which the US has shaped media in the Caribbean, the reverse has not garnered much attention. If transnationalism is a continuous circular process, as so many have argued, then we should also recognize that influence flows both ways. ${ }^{2}$ Mid-twentieth century Cuba and its diaspora offers a productive case in point, namely, the events surrounding the Cuban Revolution of 1959, including the elites and professionals that fled. Less known is how these events also brought to the US three essential groups for commercial broadcasting: media professionals, advertisers, and audiences. ${ }^{3}$ 
When explaining the making of ¿Qué Pasa U.S.A.?, the first Cuban-American show in the US, television historian Yeidy M. Rivero informs us that '[p]roducing a sitcom (...) provided an opportunity to hire some of the highly experienced Cuban television professionals who settled in Miami,' and goes on to explain that this included targeting a broadcast-savvy Cuban audience. ${ }^{4}$ Here and elsewhere, Rivero points to a broader phenomenon (and the topic of her current project): the emergence of Miami as a 'media capital' - a center for media production and distribution. ${ }^{5}$ John Sinclair has noted this development, calling Miami a hub for the Spanish geolinguistic region of the Americas while recognizing the important role Cuban immigration has played. ${ }^{6}$ This phenomenon could be the subject of a book-length study; however, some of its contours can be made visible by focusing on the Revolution's impact on US news and its reporting on Cuba, which I offer here, by using Cuban and American journalism as guides.

This article uses records from and about journalists to explore significant moments in the history of Cuba and its broadcast media and how they influenced US news media. Cuban journalists documented the turbulent 1950s Cuba with its military coup d'état, repressive government, economic recessions, and many uprisings. Cuban news media professionals were instrumental in resettlement; they helped establish exile media - a crucial part of their émigré community, which offered updates on the effort to return home and advice to exiles to help them acclimate to their new environment. At the same time, throughout the US, established news outlets were attempting to make sense of Castro and his revolutionary government, many with favorable coverage, as historian Leonard Ray Teel has shown with US journalists reporting on and interviewing Fidel Castro and his rebel force, the $26^{\text {th }}$ of July Movement. ${ }^{7}$ However, this didn’t last long. Mainstream news media professionals were forced and persuaded to accommodate anti-Castro activism, which dovetailed with the much more widespread occurrence of US news media's anti-communism, anti-revolution, and pro-reform position at the precise moment that television news divisions greatly expanded their programming, including their coverage of Cuba. ${ }^{8}$ This is not to say that the Cuban Revolution radically changed US journalism practices and its structures. Rather the Revolution (particularly when the state, in 1961, began to claim that the Revolution was Marxist from the very beginning) greatly heightened the island-nation's importance for (and, thus, visibility in) US news media, while exiles worked to shape that coverage decidedly against the Cuban state.

By exploring how events in the Caribbean shaped US news media, this work attempts to invert prevailing notions that progress comes from the north (Hollywood and US broadcast networks) and 
eventually arrives in the Caribbean and Latin America. ${ }^{9}$ Likewise, this study works against eighteenthand nineteenth-century Caribbean exiles that posit that their respective nations were incomplete and fragmented..$^{10}$ For instance, Nancy Raquel Mirabal states that 'Cuba was cast as a perpetually fragmented island that could only be reinvented and "put together" from the outside.'11 Scholarship has rightfully historized and examined this teleological vision of the Caribbean rather than reproduce it, while at the same time 'provincializing' the US, so to speak. This study is a part of a trend in scholarship that recognizes and explores the reversal of the direction of influence. Scholars in fields like US empire studies have long known how territories can shape metropoles. ${ }^{12}$ This article hopes to contribute to Caribbean broadcast literature with an exploration of how Cuba and its diaspora impacted US broadcast news media by focusing on Cuban and US journalism and their inherent transnationalism. In doing so, this work is animated by a set of questions: How has events on the island-nation and its diaspora impacted broadcast journalism in South Florida and the US, and, specifically, the coverage of Cuba on US television? Why did US journalists place so much importance on a relatively small island, and why was that coverage decidedly against the Castro regime when impartiality was the 'time honored ethical standard' of US journalism? ${ }^{13}$ Questions about Cuba's impact on the US news industry can undo antiquated paradigms by recognizing transnational forces as a continuous circulation that shapes both territories and metropoles while maintaining no illusions of an equally beneficial exchange.

In response to these questions, this study argues that the 1959 Cuban Revolution and its exiles caused the US news media industry to incorporate Cuban media professionals and audiences, accommodate Cuban exile activists, and heavily invest in the coverage of Cuba and its refugees. As a result, Cuba's visibility on US television (among other mediums) was dramatically increased and was often disparaging to the Revolution's leadership. For this reason, this paper focuses on and is structured by the above-mentioned three areas. First, the propelling of Spanish-language media, including news media in South Florida and eventually the US in general, due to the incorporation of Cuban media professionals and audiences as part of the development of Miami as a center for media production and distribution. Before 1960 there were few sources for media; however, as Gonzalo R. Soruco writes:

By the late 1980s the greater Miami area had a large number of Spanish-language media outlets: about twenty newspapers and magazines; eight AM and FM radio stations; two network television stations; and two cable stations for either local, national or international news, general information, entertainment, or opinion. ${ }^{14}$ 
Univision and Telemundo, the two major US Spanish-language networks in this era, invested heavily in Miami, including establishing nationally broadcasted Spanish-language news and distributing news from Latin American throughout the US. ${ }^{15}$ These two networks were attracted by the readily available Cuban media professionals that established regional news media as well as the growing demand for Spanish-language programming by Cuban audiences, which then grew into a major Hispanic market as the region drew in more Latina/o migrants. ${ }^{16}$

Second, the Revolution created a significant opposition in exile that sought to undermine the Cuban state in every form. Scholarship and popular discourse have always been more concerned with armed attempts to dismantle the revolutionary government in order to return home and ignored Cuban exile media activism. Though this framing is largely unheard of, it has utility in identifying and discussing the ways in which Cuban exile organizations worked to impede depictions from news reports and documentaries that placed the Revolution and its leaders in a positive light, which strengthened anti-communism and anti-Cuban state sentiments in US news media. In their quest to sway US public opinion against the Castro regime, Cuban activist groups biased the US news industry by appealing directly to media professionals and provoking US authorities to censor, what they deemed to be, communist propaganda. Ultraconservative US broadcasters also happily disseminated Cuban exile advocates' political message - that analysis, however, was left out since I address it elsewhere. ${ }^{17}$ The impact of Cuban exile media activism is difficult to measure, but, given the positive responses from media professionals, organization leaders, and US authorities and the amount of visibility given to them, it is reasonable to say that Cuban activists certainly did their part in sullying the reputation of the Cuban state and added validity to others in better positions to do the same. ${ }^{18}$ Very early on in their media activism, however, Cuban exile organizations felt forced to defend themselves from negative depictions that other Latina/o and immigrant groups faced. Crisis Amigo (1961), for instance, was a rare example of when the 'golden age' of television documentary (from commercial television) worked against the political agendas of the 'golden exiles.'

Finally, US journalist television dramatically increased the visibility of Cuba. From 1955-1958, commercial network television aired a combined five documentaries and news reports involving Cuba; however, that number jumped to 59 from $1959-1964 .{ }^{19}$ The Revolution coming into power came during a watershed moment for US television in which broadcast networks greatly expanded their news divisions and increased their documentary production as part of an attempt to improve the medium's status from its 'wasteland' status. The notorious characterization of television as a 
'vast wasteland' by Newton N. Minow, chairman of the Federal Communication Commission, marked the beginning of (what I've described as) a redeeming project. ${ }^{20}$ As many scholars have noted, this occurrence was taken up by media professionals, media executives, and US officials by offering far more coverage of relevant domestic and international issues and, in regard to the former, swaying public opinion in favor of US foreign policy during the Cold War. Consequently, this placed a special interest in Cuba, Vietnam, and their surrounding nations. ${ }^{21}$

This article could have solely focused on how television's redeeming project increased the reporting of Cuba's Revolution. However, doing so belies the more complicated and deeply transnational forces at play that go beyond representations. These include Havana having been a Latin American media capital; Cold War geopolitics with Cuba and the Soviet Union allied against the US; (events like the Bay of Pigs invasion, the US embargo, and the Cuban missile crisis); favorable US immigration policies and extremely generous resettlement aid for Cubans; broadcast-savvy Cubans that highly valued and sought out news and up-to-date information about their home nation; and Cuban exile media activism that appealed to US news professionals, partnered with US conservative broadcasters, and alerted US authorities in attempts to shape US foreign policy. These transnational connections go beyond US journalists reporting on a foreign nation.

This work's treatment and conceptualization of transnationalism follow Jorge Duany's argument 'that the form, frequency, and intensity of transnationalism largely hinges on the nature of the relationship between sending and receiving countries. ${ }^{22}$ Indeed, the Cuban Revolution and the events that ensued transformed US-Cuban relations and, in turn, transformed transnationalism between the US and Cuba. Their contentious geopolitics, exacerbated by the Cold War, dictated nearly every facet of their exchanges, directly or indirectly. Despite conventional wisdom that Cuba was completely isolated (with examples typically pointing to the US trade embargo, communist containment, and the Cuban state's 'overt agenda of fomenting autochthonous culture, ${ }^{23}$ especially with national cinema), transnational exchange between the US and Cuba was not halted but dramatically altered.

With few exceptions, the scholarships that sit at the intersections of journalism, Cuban diaspora, and Latinas/os studies have yet to investigate the ways in which Cuba or the Caribbean has impacted US media. ${ }^{24}$ Likewise, journalism and Latina/o scholarship have not given much attention to audiences' role in newsmaking. ${ }^{25}$ This is despite the fact that Latinas/os and Cuban communities have influenced regional and national news through activism and fought to be a part of their 
productions. ${ }^{26}$ This work intends to fill these gaps by mapping out the areas in US media, particularly news media, that were affected by the transnational forces surrounding the 1959 Revolution by following the incredibly useful source materials left behind by journalists. These and other sources were amalgamated from different places.

\section{Source Materials and Approach}

Examining the ways in which Cuba and its diaspora have left their mark on US media necessitated piecing together primary and secondary sources that have not previously been put together. Weaving together these sources aided in tracing and filling the gaps of how and why media in the US was impacted by events in Cuba since certain areas have not garnered much scholarly attention while others are well-researched but lack a focus on Cuba. As such, this work relies on archival research, analyzing materials from two collections from the Cuban Heritage Collection (CHC): the Luis V. Manrara Papers and the Truth About Cuba Committee, Inc. Records. Of the many types of materials (like the organization's board meeting minutes, internal memos, and literature), personal letters were very useful since correspondences between Cuban advocates, media professionals, and US authorities were quite good at displaying exiles' attempts to influence US media coverage of Cuba and the positive responses they received in fighting communist 'propaganda.'

In addition, the Library of Congress's digital collections was searched for internal documents and congressional hears. They displayed the reactions from US institutions and federal agencies like the FBI, CIA, and Congress when Cuban organizations accused broadcasters of disseminating communist propaganda over the US airwaves. While they never officially confirmed that a program was 'red' propaganda, US agencies investigated media outlets like National Educational Television (NET). These investigations later helped to justify NET's replacement with the Corporation for Public Broadcasting (CPB), a nonprofit corporation funded by the US government that established and oversaw the Public Broadcasting Service (PBS) and the National Public Radio (NPR). Archived national newspapers like the New York Times and Miami Herald were used as well as the archives of media-oriented and trade journals like Television Digest, Variety, and Back Stage.

Particularly useful in finding television programs involving Cuba was Daniel Einstein's Special Edition: A Guide to Network Television Documentary Series and Special News Reports, 1955-1979, which I highly recommended. Michael Curtin's canonical Redeeming the Wasteland was remarkably useful in 
contextualizing this distinct moment in US television. Outside of the scope of these two books, the history of the NET can be found in two dissertations, respectively, by Carolyn Brooks and Donald Neal Wood, which are used here to explain NET's main objectives to then understand why their documentaries about Cuba, among others, veered away from commercial standards. ${ }^{27}$

Work from Cuba or fundamentally built on Cuban sources include Yeidy M. Rivero's pioneering studies Broadcasting Modernity: Cuban Commercial Television, 1950-1960 and "Havana as a 1940s-1950s Latin American Media Capital.” 28 Oscar Luis López’s La Radio en Cuba published on the island and Cuban journalist Michael Brian Salwen's Radio and Television in Cuba: The Pre-Castro Era helped to further flesh out the transnational exchanges that left its marks on US media, among other works. ${ }^{29}$ These authors' works were instrumental in tracing the development of Cuban's broadcast industry and how its demise influenced US media. They show that the harsh censorship from the Batista regime, a series of economic recessions, and the Cuban Revolution were, what migration scholars call, 'push factors' for media professionals' emigration, with many (but not all) resettling in South Florida. The development of media in exile can be found in books by Gonzalo R. Soruco and Christine Lohmeier. ${ }^{30}$

Primary sources fill gaps in these works, such as news media professionals immigration like Manolo Reyes' employment in Cuban broadcasting, and then him becoming the first Cuban to have a program on an English-language channel (News En Español), Channel 4 WTVJ-TV. ${ }^{31}$ Moreover, many scholars have noted how broadcast programs were woven into the fabric of the quotidian and political life of Cubans on the island and then in exile. ${ }^{32}$ Additionally, materials from the $\mathrm{CHC}$ and local periodicals show how exile media activism swayed news coverage against the Castro regime on English-language news media and established Spanish-language news in South Florida that was decidedly anti-Castro. What follows is a historical sketch of Cuban broadcasting followed by three sections that explain Cuba's impact on US media: the incorporation of Cuban professionals and audiences, Cuban exile media activism, and US nonfiction television turning its attention to Cuba.

\section{Cuban Broadcasting and Journalism}

Cuban president Alfredo Zayas inaugurated Cuba's first 'official' radio station, PXW, on the $10^{\text {th }}$ of October 1922, and by the next year, 14 more stations spring up in Havana. ${ }^{33}$ By 1930, Havana had 
40 radio stations, and the entire island had 61 in total. ${ }^{34}$ Then, in the 1940 s, Havana-based radio networks developed and professionalized with the support of the advertisement industry and its rapid growth. ${ }^{35}$ Early amateur programs and independent stations broadcasted mostly offered news but also music. Many were extensions of newspapers and, as such employed journalists, at times, literally just reading their stories over the air. ${ }^{36}$

As prior research has shown, CMQ Radio and Radio Havana Cuba-Cadena Azul emerged as the most prominent radio networks. They fiercely competed over talent and were well-supported by advertisements in the 1940s. They broadcasted variety shows, news, music, and (the very popular) radionovelas. In fact, Cuba was the origin of radionovelas for Latin America. ${ }^{37}$ Once networks replaced small stations, Cuban radio reached a high level of professionalism with talent and administrative structure. ${ }^{38}$ These developments Rivero credits to post-WWII economic prosperity in Cuba and the implementation of the US broadcasting model, including formal practices, advertiser's formal training, and the establishment of laws that regulated the commercial system. ${ }^{39}$ In addition to an impressive pool of creative talent and media professionals from Latin America, these factors led to the success of Cuban commercial television and, Rivero argues, made Havana a media capital: ${ }^{40}$

Havana was one of the most important centers - perhaps the most important center - of commercial radio and television production in Latin America. By adapting the US broadcasting system in terms of production, programming, and advertising practices, and by gathering a workforce that mastered the technical, business, and creative aspects of radio and television, Havana's broadcasting industries became the commercial model for the region. ${ }^{41}$

This transnational process included media professionals coming from Latin American to Havana, the adaptation of US broadcast structures and formats, and the dissemination of media professionals and cultural artifacts, such as formats, from Havana throughout Latin America. ${ }^{42}$

On the ground, radio was quintessential to daily life on the island, but audiences attempted to make sense of the new medium of television. Journalists and television critics used their vision for the medium to shepherd audiences' expectations and understanding of television. In terms of the former, 'journalists interpreted television's technology for the[ir] readers. ${ }^{43}$ As previous 
research has demonstrated, reports left by journalists and source materials surrounding the news industry are invaluable components to an archive of Cuban broadcasting and can help track the rise and decline of Havana's media capital status.

The 1942 broadcast law, for instance, meant 'that only accredited journalistic organizations could be in charge of informative programming. ${ }^{44}$ Cuban television also appropriated US television formats from programs like Ante la prensa, the 'indigenized version of NBC's Meet the Press' and '[o]ne of the most prestigious and respected shows on Cuban commercial television' even before $1959 .{ }^{45}$ Journalists on Ante la prensa expressed concern over state censorship after Fulgencio Batista's coup, which was shared by other journalists and Cuban audiences. This censorship, the growth of US media imports, and the decline of the Cuban economy 'instigated a series of migratory waves of Cuban media professionals and talent off the island. ${ }^{36}$ This was the beginning of the end of Havana as a media capital, which reached its conclusion when the Revolution took power. These events occurred within the context of growing opposition to the Batista regime, including bearded rebels in the Sierra Maestra calling themselves the $26^{\text {th }}$ of July Movement lead by Fidel Castro. In the late-1950s, the US press turned on Batista and the Cuban government as they reported on rebels in the mountain fighting for liberation, typified by Herbert L. Matthews' interviews with Fidel Castro, which will be further addressed later.

In terms of the revolutionaries, Rebelde Radio was an important clandestine guerrilla radio operation that broadcasted news, music, and spoken literature to Cuba as a means to spark resistance against Fulgencio Batista's dictatorship and to shore up support for the Revolution. ${ }^{47}$ As Barlow argues: 'Once on the air, the broadcasts were instrumental in galvanizing public opinion favorable to the revolution. In both Cuba and Nicaragua, the evidence indicates that clandestine broadcasts were indispensable to the mobilization of popular support for the rebels before their conquest of state power. ${ }^{48}$ Alejandra Bronfman corroborates this claim and expands it to the Caribbean, stating that 'In this region, radio was from its inception imperial and transnational, a feature that could both bolster centres of power and contribute to their undoing. ${ }^{49}$

As repression of the media and press in Cuba grew, so did the desire of news media professionals to leave the country; Rivero states that 'the political censorship that began to take place after Batista's military coup, and that was mandated by law in 1957, probably compelled several media professionals (particularly journalists) to leave the country. ${ }^{50}$ Media professionals found work in the Caribbean like the Dominican Republic and Puerto Rico, as well as the circum-Caribbean region of Mexico, Central 
America, and South America. However, because the greater Miami area would become home to the Cuban ethnic enclave, South Florida would gain Cuban media professionals and audiences that propelled US Spanish-language news media.

\section{Incorporation of Cuban Media Professionals and Audiences}

The waves of exiles that arrived after 1959 in the US generally began with the most affluent and declined in social standings. They were processed and assisted by the Cuban Refugee Program in downtown Miami. While many settled in different parts of the US forming communities in New Jersey, California, and Michigan, South Florida formed the largest (oft-eclipsing) émigré community. From different locations, they were united by their exile status, anti-Castro sentiments, and deep desires to return home while still carving out a place in their host nation. It is important to note that Cubans have migrated to the US and Florida well before 1959, for example, Afro-Cubans in Tampa and New York. ${ }^{51}$ However, the post-1959 exiles were distinct in that they brought with them media professionals and broadcast audiences that would help to develop Spanish-language media in South Florida and news media with it. ${ }^{52}$ Indeed, before 1960 there was one newspaper and three radio stations serving the Spanish-language audience. Only after a decade of Cuban resettlement and attracting other Latin American migrants to the region, according to Soruco.

The growing presence of Hispanics in South Florida during the 1970s and 1980s resulted in an unprecedented expansion of the local Spanish-language mass media. ${ }^{53}$ Such growth began modestly with periodicals and radio. Radio in Cuban communities was a permanent fixture. Radio was thought of as 'the Cuban medium,' and Christine Lohmeier has noted that 'radio stations and the journalists employed in them are by far the strongest forces in safeguarding and fortifying an exile mentality. ${ }^{54}$ It comes as no surprise that Cubans quickly bought air time, sought and gained employment by stations, and modeled programs after ones in pre-1959 Cuba. ${ }^{55}$ Readily available Cuba news professionals like anchorman, journalist, and producer Manolo Reyes and the News Director of 'La Cubanísima' Salvador Lew made this possible, along with a growing Spanish-listening audience.

Radio served a dual function that exemplified the inherent dichotomy of a community that often was defined by an astonishing effort to return home and an equally astonishing ability to acclimate. Cubans sought to stay abreast of developments to remove Castro, like the many reports leading up to the Bay of Pigs invasion. ${ }^{56}$ On the other hand, radio was also instrumental in forming an 
imagined community (much like it has done for other Latina/o immigrants), and it helped to acclimate newly arrived Cubans with informative programs. ${ }^{57}$ Indeed, 'Radio announcers provided information on community services and answered questions about taxes, health care, education, the legal system, and even the weather. 58

In greater Miami, as noted by historians, WFAB 'La Fabulosa' (The Fabulous One) became the first completely Spanish-language radio station in Florida, which was followed by WQBA 'La Cubanísima' (The Most Cuban) in 1965. Ten years later, WRHC Cadena Azul became the first Cuban-owned radio station and was named after a station in Cuba. Radio Mambí was another station brought out by Cubans in the mid-1980s, with their target audience being 'historic exiles. 59

Television, on the other hand, had a difficult time making headway, which made it impressive when Manolo Reyes, in 1960, became the first Cuban to have his own program on an English-language channel: News En Español (Channel 4 WTVJ-TV). ${ }^{60}$ Reyes was 'a veteran of 22 years in Cuban broadcasting. He's been an actor, director, producer and radio sales manager,' Jack E. Anderson of the Miami Herald reported. ${ }^{61}$ Reyes pitched News En Español to the WTVJ's founder, Mitchell Wolfson, and the well-regarded news director and vice-president of news for WTVJ-TV, Ralph Renick - who was particularly supportive of Reyes. However, the station had no Spanish-listeners to evaluate the show, as Reyes recalls: 'I did the pilot program and they had to show it to a linguistic professor at the University of Miami because no one at Channel 4 spoke Spanish.' ${ }^{62}$

Although an initial obstacle, the lack of Spanish-speak TV professionals in the early 1960s ultimately helped to secure the success of News En Español since there was no competition and high demand for Spanish-language news on TV. It would be twenty-six years before the two (yet to be formed) dominant Spanish-language networks, Univision and Telemundo, created their news programs in Miami. Before that time, Cubans complained to television broadcast stations for not discussing relevant issues to their community. ${ }^{63}$ Indeed, Cuban journalist Guillermo Martinez praised Reyes' news program, stating that 'Cuban exiles would turn on his show to get their television news. It was the only place they could get it. ${ }^{64}$ Likewise, Anderson stated that ' $\left.\mathrm{t}\right]$ hey have the kind of substantial, guaranteed audience that other performers and programmers have been known to dispense sweat, tears and stacks of folding stuff to get and keep. ${ }^{35}$ During this time, Reyes broke a number of stories like Castro's military plans for Angola, underground jails in Cuba, and the Soviet arms build-up in Cuba. ${ }^{66}$ Reyes' work in the news industry allowed him to become a frequent contributor to Walter Cronkite's CBS Evening News and win an Emmy for broadcast journalism. ${ }^{67}$ 
Reyes was also prominent in the émigré community; he was frequently featured in periodicals and appeared at several events. ${ }^{68}$ Even with this pioneer, Spanish-language television initially developed slowly but eventually picked up in the 1970s and onwards.

In 1969, Tele-Cuba, Inc. (a seven-man group of local and foreign investors) sought out to change the media landscape when they bought ' 43 weekly hours' of air time on WAJA-TV and prepared to roll out 'a wide variety of Spanish-language shows seven days a week.'69 Their programming was marked by pre-Revolution Cuban broadcasting. Journalist Frank Soler states:

The general directors of Tele-Cuba, Cuban exiles Jose Alfredo Lopez - known as Joalo - and Aramis del Real, say plans call for a variety shows running the gamut from kiddie programs to Spanish-speaking movies, variety spectacles, talk shows, soap operas, dramas, amateur and youth-oriented programs, sports and newscasts. ${ }^{70}$

This programming is similar to what was offered in Cuba. Soler called Lopez 'a veteran of more than 30 years in radio and television,' which included his time in Cuba. Aramis Del Real also had experience in broadcasting as a writer of the popular series Pepe Cortéz on Santa Clara’s radio station CMHI, among other positions. ${ }^{71}$ Lopez promised WAJA-TV would provide 'a major news show at noon daily, with five-minute newscasts interspersed throughout the day. ${ }^{72}$ Tele-Cuba was a predecessor to a much larger and national expansion of Spanish-language media that included Miami. Through the Spanish International Communications Corporations (SICC), the Spanish International Network (SIN) bought out WAJA-TV, renaming the station WLTV. ${ }^{73}$

The Mexican-based SIN provided the feed while the American-owned SICC held the station licenses due to restrictions on broadcast stations, mainly with regard to foreign ownership. ${ }^{74}$ In reality, the Azcarraga family (a media dynasty in Mexico) was in control of them both. By 1962, SIN (through SICC) acquired San Antonio's KWEX-TV and Los Angeles' KMEX and continued to grow. ${ }^{75}$ Jillian Baez states that '[i]n the mid-1960s to early 1970s, SIN expanded to nine US stations, which included four stations on the Mexican side of the border that broadcast into the United States.' They provided some local and mostly international news reporting, which was station-specific; however, in 1981, 'SIN launched a US-based national news network to provide local news and public affairs programming for Latina/o. 76 
This was, however, before Spanish-language broadcasting took on a panethnic Latina/o vision and instead provided programming based on region and national Latina/o groups. Attempting to accommodate the three largest populations, SIN and SICC developed a tripartite formula that encompassed of Mexican programming in the Southwest of the US, Mexican and Puerto Rican programming in the Northeast, and Mexican and Cuban programming in South Florida. Mexican programming was the basis for all three regions because distributing SIN's Mexican programs was far less expensive than producing new programs. It was also cost-effective to supplement that programming by buying preexisting programs from Puerto Rico. However, South Florida was a special case that prompted local production. Getting programs from Cuban national television and showing them in South Florida was certainly not an option as they did with Puerto Rico. Cubans, even before SIN's expansion, demanded content relevant to their exile and resettlement that also incorporated local Cuban talent. ${ }^{77}$ Additionally, G. Cristina Mora informs us that offering Mexican programming to Cubans refugees also proved problematic because of the exile community's growing animosity towards Mexican leadership for buddying up with Cuban leaders. At that time, anything and anyone associated with Mexico could be labeled pro-Castro. In the end, the president of SICC, Rene Anselmo, and WLTV's general manager, Joaquin Blaya, agreed that original production was the best option. 'After several discussions with Anselmo, Blaya resolved this issue by investing in WLTV production studios and creating several Miami-based news and information shows. ${ }^{78}$

In 1985, WSCV began to broadcast Spanish-language media, including news challenging WLTV's cornered market just as its license was being challenged and eventually revoked in $1986 .{ }^{79}$ WSCV would be acquired by Telemundo in 1987, along with stations in other prominent Hispanic markets like San Juan, Puerto Rico. ${ }^{80}$ In the same year, due to regulatory, legal, and political issues, SICC was sold to and renamed Univision by Hallmark Cards Inc. and First Chicago Venture Capital. ${ }^{81}$ This, and the launching of Telemundo a year prior, placed Spanish-language television on the path of a duopolistic rivalry. Competing in programming, they mirrored each other. For instance, Univision and Telemundo established their news services in Miami around the same time. ${ }^{82}$

News programs like Noticiero Univision and Noticiero Telemundo covered stories from the US and Latin America. The two networks picked Miami for a good reason. John Sinclair notes that national news broadcasting in the US necessitated an easternmost time zone and that Miami offered this as well as a location within the Spanish-language geolinguistic region along with Spanish-language media professionals and audiences. ${ }^{83}$ Their national broadcasting news programs moved away from regional and 
Latina/o subgroup specificity to a national and universalizing model. ${ }^{84}$ Univision's and Telemundo's efforts towards constructing a pan-Latina/o audience were epitomized by their encouragement of anchors to practice 'Cronkite Spanish,' that is to say, a 'neutral' Spanish that could play to all Spanish-listeners. ${ }^{85}$

The events accounted here placed Miami on a path to become the 'Hollywood of Latin America,' a status John Sinclair sought out to verify. He concluded that the city was 'a significant center for the whole geolinguistic region of the Americas for the production and distribution of television (not film), with synergistic links to the music and convergent communication industries. ${ }^{96}$ The media activism by Cuban exiles also left its mark, however, for English-speaking programs.

\section{Cuban Media Activism}

Cuban media activism of the 1960s to the 1970s largely focused on tarnishing the reputation of the Revolution and communism in US media. They departed from their Latina/o activist contemporaries who sought to get rid of negative depictions and increase employment in media production. Before this, however, there were moments in which Cuban exile media activism aligned with US Latinas/os (and other marginalized groups) that focused on disparaging depictions. One primary example was Cuban exile groups' working against Crisis Amigo (1961), a television documentary that expressed contempt for the new Cuban arrivals, which reflected and exacerbated xenophobic and antiimmigrant sentiments against Cubans in South Florida. Before entering into the details, it is important to note that if the documentary's accusations were to spread, it would impede the work of Cuban activism by undermining their legitimacy.

Cuban exile media activists were appealing to US news professionals because they used 'proper' (class-based) decorum and were professional; were often white, male, and staunchly adherent to heteronormativity, and; supported American ideals like democracy and Christianity. These elements legitimized them and their claims about Cuba and, thus, made it easier to convince US news professionals of the ills of the Revolution. Indeed, journalists often treated them as unbiased experts of Cuba, a source for information about happenings on the island. However, being viewed as 'subversive' like Chicana/o and Puerto Rican activists or stereotyped as Latina/o criminals, as Crisis Amigo attempted to do, would hamper Cuban exile activism. Cuban organizations and audiences worked against the documentary, and the makers of Crisis Amigo, like other news media professionals, learned to consider the consequences of offending the Cuban community. 
Late in 1961, Channel 7 WCKT's promotions of Crisis Amigo claimed that their television documentary was an honest exploration of the issues surrounding the arrival of Cubans in South Florida. ${ }^{87}$ Cubans, on the other hand, felt the opposite and were livid when WCKT broadcasted this 30-minute documentary produced by Gene Strul, Wayne Fariss, and Max Moore. Cuban observers stated that this documentary was not only fictitious but offensive for casting Cubans as drug dealers, prostitutes, and gang leaders. ${ }^{88}$ Indeed, congressional records corroborate these allegations about Crisis Amigo. In a transcript of the documentary from a congressional hearing on the so-called 'Cuban Refugee Problem,' Crisis Amigo's narrator claims that 'With the Cuban refugees, (...) we have imported everything from petty thieves to narcotic pushers.' The narrator continues by adding, 'About the only racket unorganized is prostitution,' and that 'Gangs of Cuban and American youngsters are forming. ${ }^{89}$

As a consequence of the émigré community's outrage, WCKT was required to give airtime to voices of dissent that was equal in duration to Crisis Amigo, which was a part of an FCC regulation commonly referred to as 'equal time.' Jack E. Anderson of the Miami Herald (not to be confused for the syndicated Jack Anderson) reported that 'Alberto Gandero, who represented the Cuban Rotarians but was also a Spanish newscaster for competing Ch. 10., called "Crisis Amigo" unethical, "unpatriotic, deceitful, and full of falsehoods." ${ }^{90}$ Likewise, the Confederation of Cuban Workers in Exile (CCWE) responded with a public statement that proclaimed that '[Crisis Amigo is a] sad spectacle of the greatest offense against our mothers, wives, daughters, calling them prostitutes (...) [it] also accused us as of being marijuana smokers and drug dealers, which is slander that we strongly reject. ${ }^{91}$ WCKT would have to answer for their documentary.

Gene Strul, WCKT's news director and one of the producers of Crisis Amigo, was forced to appear before the Subcommittee to Investigate Problems Connected with Refugees and Escapees to defend the documentary. ${ }^{92}$ Unknowingly, Strul, Fariss, and Moore stepped into a highly politicized subject; they had possibly not considered or underestimated the political, geopolitical, and financial investments by the federal government and the State of Florida in making Cuban resettlement go smoothly. ${ }^{93}$ Their initial response was to defend Crisis Amigo, essentially arguing that they had followed journalistic standards. However, feeling the pressure of the federal and local government, the makers of Crisis Amigo began to back down and called for unity among Americans and Cubans while blaming miscommunication. Wayne Fariss stated that he 'wished to impress its viewers that the interest of good Cuban citizens and good American citizens were identical (...) that it was regrettable 
that so many people miss-interpreted Ch. 7's intentions. ${ }^{94}$ Unsurprisingly, the broadcast of the documentary was cut short. Another Cuban exile group, the Truth About Cuba Committee (TACC), also called for unity between Cubans and Americans; however, they did so as a means to defeat communism via media activism. ${ }^{95}$

Cuban organizations shaped the news industry in the greater Miami area by persuading American and Cuban news media professionals to present anti-Cuban state sentiments on their programs, which was largely led by the TACC. Their first step was to identify and locate news outlets and news media professionals. In an internal memo, the TACC tasked their employees to compile lists of media news outlets in order to disseminate their literature and to establish correspondences. They specified that these lists should include news directors, reporters, news services, and any and all media professionals from 'national and international newspapers, magazines, radio and TV.' 96 The TACC fed news media professionals anti-Cuban state and anti-communist propaganda, which was presented and often treated as information - regardless of how blurry the line between the two can be and the clear agenda of exile organizations.

President of the TACC, Luis V. Manrara, proudly stated that 'we issued and distributed a large number of publications, conservatively estimated at over one million copies from about 550 books, brochures, reports, fliers, etc., both in English and Spanish. ${ }^{97}$ Manrara authored most of TACC's publications, including their more popular books An Exposé of the Insidious Film' Three Faces of Cuba' and Betrayal Opened the Door to Russian Missiles in Red Cuba. These and other publications were sent to six nearby television stations such as Channel 4 WTVJ-TV (CBS), Channel 10 WPLG-TV (ABC), Channel 6 WCIX-TV, Channel 10 WPLG-TV, Channel 2 WTHS-TV (NET), and Channel 23 WAJA-TV, and radio stations like WMET, WMBM, WFAB, and WMIE (later WQBA). ${ }^{98}$ News media professionals such as news directors, station managers, news anchors, and journalists, among others, received their literature with positive responses.

The leaders of the TACC like Manrara, Gerardo Abascal, and Jesús M. Guzmán not only sent publications but also words of encouragement. In a letter to Ralph Renick, Manrara stated, 'I hope you can publicize the attached letter to Senator Dodd or excerpts thereof, in your very widely known program. ${ }^{99}$ The letter expressed Manrara's concern over communism in Cuba and asking the Senator to take action. Likewise, Manrara wrote to a television program on Channel 7: 'We wish to congratulate you for the excellent program entitled "I May See,"' and he congratulated them for 'exposing the evils of Communism. ${ }^{100}$ The TACC sent letters to Ken Taylor, news director for television and radio, and 
on-air talents like Larry King and Barbara Walters. Regarding their fellow exiles, the TACC tapped into their national loyalty. Manrara wrote to Norman Díaz, for instance, and stated, 'I am very grateful for the act of kindness by offering to broadcast on your very popular television program information by the TACC in defense of our homeland. ${ }^{101}$ Manrara played on Díaz's patriotism to further the TACC's cause, just as they have done with other Cuban exiles like reporter Humberto A. Estévez of Channel 23 WAJA-TV and News Director Salvador Lew of WQBA. Within their ethnic enclave, and with their fellow Cubans, Cuban activists used Cuban national pride to compel Cuban news media professionals. Devotion to the ‘liberation' of Cuba was an incredibly strong motivator, and anything less was often fiercely condemned in the exile community. For programs that, from their view, strongly supported the Revolution, Cuban exile activists took a more aggressive approach by involving US authorities.

The producers of television documentaries like Three Faces of Cuba, Report from Cuba, and Fidel experienced the consequences of upsetting the Cuban exile community. Cuban organizations like the TACC and the Committee Pro Cuba Liberation (CPCL) from Hartford, Connecticut, involved the FBI, CIA, the House Committee on Un-American, the Senate, and the Congress implying them to intervene in these 'communist' broadcastings. ${ }^{102}$ The director of Three Faces of Cuba, Robert Carl Cohen, blamed his hardships with the IRS and missing copies of his film on Cubans. Journalists Saul Landau and filmmaker Richard O. Moore saw their documentary Report from Cuba protested in New York, Boston, and Miami. Moreover, Fidel (1969) was picked up by only 1/3 of local NET stations in the US, while the rest opted to avoid controversy. A few stations even had bomb threats after offering programs that did not denounce Cuba authorities; however, no one took responsibility. ${ }^{103}$ The documentaries mentioned here were a part of NET's campaign to become the 'fourth network' with controversial programming that departed from the practices of commercial television. The commercial television networks, however, dovetailed with Cuban exiles' efforts against communism. ${ }^{104}$

\section{Televising the Revolution}

The significant increase in Cuba's visibility was, in large part, due to a particular moment in US television history. ${ }^{105}$ The 'golden age' of television documentaries was an era marked by a significant commitment by the three major commercial networks - ABC, NBC, and CBS - to increase news reporting and television documentaries. In the late-1950s and early-1960s, US commercial television 
played a significant role in Cold War politics and public opinion on foreign policy, despite operating at times at a financial loss. Michael Curtin describes this period as 'a distinctive and complicated moment when political and corporate leaders, as well as network officials, embraced the television documentary in an explicit attempt to mobilize public opinion behind a more activist foreign policy. ${ }^{106}$ Nearly four hundred programs aired in 1962, with an estimated 90\% of American households watching at least one documentary per month, according to Curtin. ${ }^{107}$ News media professionals felt it was their duty to cover and analyze important issues surrounding the Cold War and the social movement era. One of those issues was the Cuban Revolution.

In 1961, Castro came to power and Cuba entered the Cold War by allying with the Soviet Union. The island-nation received unprecedentedly high visibility to the American public. Prior to the Cuban Revolution in January of 1959, Cuba lacked a presence on US televisions. As stated previously, from 1955-1958, the commercial networks aired a total of five documentaries and news reports involving Cuba. However, in 1959 alone there were eight and from 1960-1964 there were 51. ${ }^{108}$ Of those documentaries and reports, thirteen came in 1961, the year of the Bay of Pigs and Fidel Castro's public proclamation that he (and by extension the state) was Marxist-Leninist. In 1962, the year of the Cuban missile crisis, there were 21 documentaries and news reports.

Of these documentaries and special reports, many were made and hosted by television newscasters and reporters. Well-known journalist Chet Huntley covered Cuban issues frequently. The Chet Huntley Report documentary series addressed Cuba 11 times between 1959-62. Likewise, the highly successful Eyewitness to History series also addressed issues surrounding Cuba just as often and was noted as 'the most technically advanced news show of the time. Its production values and techniques were elaborate and innovative (...) its content was timely and exclusively hard-news oriented. ${ }^{109}$ Journalists Peter Kalischer, Howard K. Smith, Richard C. Hottelet, Stuart Novins, and Blaine Littell worked for Eyewitness to History and often reported on Cuba. ${ }^{110}$ These reports, and many other documentaries and special reports, did not paint the island-nation favorably; however, this was not the case in the late 1950s.

In 1957, Herbert L. Matthews of the New York Times famously reported that Fidel Castro was not, in fact, dead as previously claimed by the Batista regime and reported by others like the Times. Matthew traveled to the mountainous region of the Sierra Maestra to report on the activities of Fidel Castro and the $26^{\text {th }}$ of July Movement. His three-part article started with a front-page article with the headline that read "Cubans Rebel Is Visited in Hideout: Castro Is Still Alive and Still 
Fighting in Mountains.” Matthew (along with Robert Taber at CBS, Karl Meyer at the Washington Post, and Jules Dubois from the Tribune, among others) offered such favorable reports that they received gold medal awards from Castro after 1959 that read 'Sierra Maestra Press Mission to Our American Friends with Gratitude' with a signature from the revolutionary leader. For Leonard Ray Teel, historian of US journalism, Castro had manipulated these thirteen American journalists. While Teel is excessively concerned with the ways in which these US journalists departed from US journalism's ethical standards of impartiality and consequently fell 'victim' to Castro, he rightfully points out how Castro masterfully used the US press to his advantage and gaining support from Americans

In these pre-1959 interviews, Castro claimed to support American ideals of fighting for liberty, democracy, and free elections while making no mention of Marxism or US imperialism. He expressed his intentions of reinstating the 1940s Cuban constitution and revitalizing the economy. Castro also made use of optics during these interviews. For example, he duped Matthew by making one group of soldiers march back and forth outside interviews to appear as if he had a much larger army. ${ }^{111}$ This positive coverage for the Revolution grew to included broadcasting.

Castro's thirteen journalists helped to bring the Revolution into the mainstream; Teel notes: 'The U.S. media stream during 1957 followed the revolution's progress with photographs, film, maps, and even Castro's voice in broken English. ${ }^{\text {112 }}$ In the same year, as noted by Rivero, CBS News Special Report's Rebels of the Sierra Maestra favorably introduced a revolutionary figure to many Americans. ${ }^{113}$ Programs like this, and Cuba in Arms, were produced or included members of the thirteen US journalists. ${ }^{114}$

Conversely, at this time, positive coverage of the Batista regime dwindled just like Washington's support. However, one notable example was Martin Agronsky's interview with president Fulgencio Batista on NBC's Look Here, which boosted its technological innovation: 'This program, originating from the Presidential Palace in Havana, was the first live broadcast to be transmitted from Cuba via new 'over-the-air' facilities recently installed between Cuba and southern Florida and was presented through the facilities of Cuba's TV network, the CMQ.' ${ }^{115}$ The interview was certainly not enough to turn the tide of the growing support of the revolution. However, after 1961, US television quickly expressed concern over Cuba and the fate of the Caribbean.

Networks quickly turned away from sympathetic views of the Revolution while increasing their coverage. Many reports were framed as investigations of what went wrong in Cuba and its 
consequences for the US, the Caribbean, and Latin America. Such was the case with CBS's Cuba's Trial, which was 'A look inside Cuba today including scenes of the trial of last year's ill-fated Cuban invasionary force. ${ }^{116}$ Moments that did not fit neatly into this narrative were forced back into place.

In the documentary 'Cuba, sí, Yanki no,' a young Cuban woman expressed that she and the Cuban people love their leader. Curtin describes this moment: 'she spots the camera, she smiles broadly and crows in English (...) “we love Fidel because he’s our leader for always. Please tell this to the United States, please, please.” However, she is dismissed since "her affirmation cannot be read as sincere. Rather, it must be seen as part of the orchestrated delirium that is characteristic of Communist politics.'117 To make sense of this moment, 'Cuba, sí, Yanki no’ dismisses the Cuban women and invalidates her views; they are explained away as products of communist manipulations. Beyond just citizens under communism, revolution, in general, was not to be trusted. 'Time after time,' Curtin informs us, 'the programs made a case for programmatic reform and modernization as opposed to violent and chaotic revolution.' ${ }^{118}$ Television documentaries and special reports did not seriously consider revolution as a feasible or civilized solution. Another focus of these documentaries on Cuba was communist containment in the Caribbean.

The coverage of the Caribbean, West Indies, and circum-Caribbean was often underpinned by suspicions of communist contamination radiating from Cuba. The Communist Assault on Latin America, for example, marketed itself as 'A look at the impact of Cuba, the first communist nation in the Western Hemisphere, on the rest of the region.' An unnamed report of the same year suggested that the Dominican Republic was next when it compared the nation's situation under dictator Rafael Trujillo and Cuba's situation before the Revolution with Batista. ${ }^{119}$ Other network documentaries included notions of containing Cuban communism like Castro Quarantined and Guatemala on the Verge. ${ }^{120}$ However, there were a few caveats to US television's anti-revolution leanings. Reporter Lisa Howard's televised interviews with Fidel Castro and Ernesto 'Che' Guevara were not completely damning and even humanized the revolutionary leaders while still taking them to task. ${ }^{121}$ Other reposts even claimed that Howard and Fidel had an affair. Either way, Howard's ability to gain access to these leaders was extremely difficult for most at the time. In fact, some have claimed that Howard acted like a conduit between Kennedy and Castro, working towards melding Cuba-US relations. ${ }^{122}$ Howard is a fascinating figure that warrants more attention. However, her treatment of Cuba was rare in the early- to mid-1960s but not unfounded. NET, in this regard, went further by departing from network standards. 
Often overlooked in histories of US television, NET made aggressive attempts to make themselves the 'fourth network' by providing provocative programming. ${ }^{123}$ At the time, NET could not compete with commercial television and, thus, devised a plan to nap viewers. NET recognized that they could cash in on the polemic era with 'controversial' yet educational programs, which fell outside of the commercial network's redeeming project. Documentary series like Changing World were included and covered Marxist nations and claimed to proffer an 'honest' exploration. NET justified these programs with democratic imperatives. In National Educational Television Program Philosophy and Purpose, NET states that:

[c]onflict of ideas is implicit in a democracy, and controversy is the soul of democracy. Ideas are to be countered by ideas and not by repressive techniques. Open minds, free discussion, vigorous debate - these are essential to good citizenship and effective community action. NET, in its public affairs, must give exposure to controversial views and must probe and analyze the significant issues and conditions of society wherever they appear (...) That is part of the overall purpose: to challenge Americans to accept the obligations of citizenship. ${ }^{124}$

NET positioned its provocative programming as catalysts for US citizenship; thus, it was not television that needed redeeming but the American's sense of national responsibility. For not following the lead of commercial networks, NET faced a backlash from Cuban exiles and US conservatives, which placed educational broadcasting on the pathway to years of Republican opposition. ${ }^{125}$

\section{Conclusion}

Events in Cuba, many of which were in and of themselves a part of transnational exchanges, left their mark on the US and with a distinct impact on US news media. The demise of Havana into a media capital for Latin America, the hardening of the Batista regime, uprising resulting in revolution, and new Cuban leaders led by Castro allying with the Soviet Union consequently formed a broadcast-savvy opposition in exile bent on sullying the Revolution while bringing Cuba to the attention of US news media. 
In the 1960s-1970s, Cuban media professionals and audiences wove themselves into the fabric of South Florida's media, which initiated an expansion of US Spanish-language broadcast and print news in the region and later throughout the nation. The Cuban media professionals in exile were often a part of the media industry in Cuba or had some knowledge of it. Many Cuban journalists either started in the news industry while in Cuba or were a part of Cuban broadcasting in another capacity and took on some form of journalism in exile. Havana being a media capital for Latin America meant that Cubans were well-informed about broadcasting as professionals and as audiences. As scholars have demonstrated, this initial expansion of US Spanish-language media caught the attention of Univision and Telemundo, leading them to invest heavily in Miami just as they were implementing a national expansion that would solidify them as the two major Spanishlanguage networks in the US. ${ }^{126}$ While the Spanish-language news and information industry in South Florida was decidedly anti-Castro, Cuban exile media activism understood that it was imperative to get their political message to the rest of America by influencing English-language news media.

Cuban media activism of the 1960s-1970s was defined by efforts to pit US media against the Castro regime and communism. For this reason, they often targeted news production and educational television rather than scripted television and radio shows. Cuban media activism can usefully be divided into two forms: persuasion and intimidation. Cuban organizations emboldened news media professionals to express anticommunist and anti-Cuban state sentiments on their programs, which was markedly effective with regional news. They appealed to media professionals' sense of morality, Cuban patriotism (when applicable), and belief in US national security to combat anti-communism. However, these were not explicit partnerships with media professionals like the ones with ultraconservative broadcasters, which reached across the US. ${ }^{127}$ In their more aggressive form, Cuban exile activism aimed to intimidate media by picketing, boycotting, voicing complaints to media outlets, and alerting US authorities to act against "proRevolution' media. However, early in their arrival, representations of Cubans like the ones found in Crisis Amigo jeopardized Cuban exiles' reputation and, by extension, the legitimacy of Cuban organizations. Cuban émigré community and their organizations quickly corrected this negative perception with the help of the federal and the Floridian government. They also received unsolicited help from mainstream news in their efforts against the Cuban state.

Commercial television gave much attention to Cuba through news reporting, special reports, and documentary series during a particular moment in which US television placed a renewed interest 
in the 'public interest' by heavily investing in keeping US citizens well-informed of domestic and international matters. This watershed moment in US television covered the social movement era and the Cold War and, in terms of the latter, served US foreign policy. Cuba was attributed importance because of its Revolution and its alliance with the Soviet Union, as well as the fear of communism contamination in the Caribbean and Latin America. Events like the failed Bay of Pigs invasion and the Cuban missile crisis further increased US coverage.

In sum, the events surrounding the Cuban Revolution of 1959 help to lay the foundation for Miami to become a center of media production and distribution for the Spanish-language geolinguistic region. Broadcast news media in Cuba and in exile were instrumental in that development as well as their media activism. The Revolution's opponents cleverly tapped into US news media and swayed them away from showing sympathy for Cuba's new leaders or implored US authorities to get involved. That activism dovetailed with the US news industry's coverage of Cuba and their investigation of what went wrong in Cuba.

The island-nation's impact on US news media is not well-known. Neither is their impact on the activism by marginal groups throughout the US during the social movement era. The Latinx movement, Black Power movement, and the New Left drew from the island's revolutionary aesthetics, ideology, and militancy. The media activism of groups like Justicia and artists like Chicanx and Puerto Rican filmmakers were emboldened by the Cuban Revolution, and it shaped them, their art, and the ways in which they challenged the U.S. media industry for inclusion.

\section{Notes}

1. Alejandra M. Bronfman, Isles of Noise: Sonic Media in the Caribbean (University of North Carolina Press, 2016); 87-96; Yeidy M. Rivero, Broadcasting Modernity: Cuban Commercial Television, 1950-1960, (Durham; London: Duke University Press, 2015); Yeidy M. Rivero, "Havana as a 1940s-1950s Latin American Media Capital," Critical Studies in Media Communication 26, no. 3 (August 2009): 275-93; and Yeidy M. Rivero, Tuning Out Blackness: Race and Nation in the History of Puerto Rican Television (Durham: Duke University Press, 2005). William Barlow, "Rebel Airways: Radio and Revolution in Latin America," Howard Journal of Communications 2, no. 2 (March 1990): 123-34; Canute W. James, “Caribbean Media Convergence: Towards a New Caribbean Journalist," Caribbean Quarterly 58, no. 2 -3 (June 1, 2012): 28-42; and Oscar Luis López, La Radio en Cuba (Havana: Editorial Letras Cubanas, 1981). 
2. Jorge Duany, Blurred Borders: Transnational Migration between the Hispanic Caribbean and the United States (Chapel Hill: University of North Carolina Press, 2011).

3. Yeidy M. Rivero, “Interpreting Cubanness, Americanness, and the Sitcom: WPBT-PBS’s ¿Qué Pasa U.S.A.? (1975-1980)," in Global Television Formats: Understanding Television across Borders, ed. Tasha G. Oren and Sharon Shahaf (New York: Routledge, 2012), 104-22.

4. $\quad$ Ibid., 96.

5. This is work-in-progress and has been presented at several events: Yeidy M. Rivero, The Original Miami Sound Machine: Cuban Exiles, the Cold War, and the Emergence of Miami as a Media Capital; and Rivero, “Havana as a 1940s-1950s," 2009.

6. John Sinclair, “The Hollywood of Latin America," Television \& New Media 4, no. 3 (August 1, 2003): 211-29, 225.

7. Leonard Ray Teel, Reporting the Revolution: How Castro Manipulated American Journalists (Louisiana State University Press, 2015).

8. Michael Curtin, Redeeming the Wasteland: Television Documentary and Cold War Politics (Rutgers University Press, 1995), 83.

9. The logic that sees media develop in the U.S. and progressing down to the Caribbean works similarly to Dipesh Chakrabarty's critique of western historicism. See Dipesh Chakrabarty, Provincializing Europe: Postcolonial Thought and Historical Difference, (Princeton, NJ: Univ. Press, 2008).

10. Jesse Hoffnung-Garskof, Racial Migrations: New York City and the Revolutionary Politics of the Spanish Caribbean (Princeton, NJ: Princeton University Press, 2019); Nancy Raquel Mirabal, Suspect Freedoms: The Racial and Sexual Politics of Cubanidad in New York, 1823-1957, (New York: New York University Press, 2017).

11. Mirabal, Suspect Freedoms, 2017, 9.

12. See Amy Kaplan and Donald E. Pease, eds., Cultures of United States Imperialism, (Durham: Duke University Press, 1993).

13. Teel, Reporting the Revolution, 4.

14. Gonzalo R. Soruco, Cubans and the Mass Media in South Florida, (University Press of Florida, 1996), 34.

15. Cuban audiences demanded programs that spoke directly to their exile and resettlement, as well as airtime for talent from their community. See G. Cristina Mora, Making Hispanic: How Activist, Bureaucrats, and Media Constructed a New American, (The University of Chicago Press, 2014), 134. John Sinclair, “The Hollywood of Latin America," Soruco, Cubans and the Mass Media in South Florida, 34

16. See Soruco, Cubans and the Mass Media in South Florida. 
17. Richard Mwakasege-Minaya, "Exiled Counterpoints: Cuban Exile Reception, Conservative Media Activism, and the National Educational Television (NET) Network," Chiricú Journal: Latina/o Literatures, Arts, and Cultures, 4, (2), Spring 2020; and Richard M. Mwakasege-Minaya, “Cold War Bedfellows: Cuban Exiles, US Conservatives, and Media Activism in the 1960s and 1970s." Historical Journal of Film, Radio and Television 41, no. 1 (January 2, 2021): 114-35. (Published online September 22, 2020).

18. Mwakasege-Minaya, “Cold War Bedfellows.”

19. These figures come from focusing on the number of programs involving Cuba in Daniel Einstein's Special Edition: A Guide to Network Television Documentary Series and Special News Reports, 1955-1979. However, they don't include the non-commercial television as these figures are not readily available.

20. The redeeming project was not only to redeem television as a medium but also to uplift the intellect and the political engagement of US citizens. It was underpinned by a democratic ideal that citizens must be well-informed in order to participate in a democracy and to take up their civic duties.

21. Curtin, Redeeming the Wasteland, 3.

22. Duany, Blurred Borders, 7.

23. Ann Marie Stock, On Location in Cuba: Street Filmmaking during Times of Transition, (University of North Carolina Press, 2009), 22.

24. Rivero, The Original Miami Sound Machine; and Sinclair, "The Hollywood of Latin America."

25. Robert E. Gutsche Jr, “The State and Future of Television News Studies: Theoretical Perspectives, Methodological Problems, and Practice," Journalism Practice 13, no. 9 (October 21, 2019): 1034-41, 1039; and Robert E. Gutsche Jr et al., “Reciprocal (and Reductionist?) Newswork,” Journalism Practice 11, no. 1 (January 2, 2017): 62-79, 64. For some works on Latina/o audiences see Jillian M. Báez, In Search of Belonging: Latinas, Media, and Citizenship (Urbana: University of Illinois Press, 2018); and Lucila Vargas, Latina Teens, Migration, and Popular Culture, (New York: Peter Lang Pub, 2009).

26. Chon Noriega, Shot in America: Television, the State, and the Rise of Chicano Cinema, (University of Minnesota Press, 2000); América Rodriguez, Making Latino News: Race, Language, Class, (Sage Publication, 1999); and Arcelia Gutiérrez, "No More Prostitutes, Pimps, \& Pushers: Deploying Hispanic Panethnicity in Media Advocacy,” Critical Studies in Media Communication 36, no. 4 (August 8, 2019): 309-22.

27. Carolyn Brooks, "Documentary Programming and the Emergence of the National Educational Television Center as a Network, 1958-1972,” (Ph.D. dissertation, University of Wisconsin - Madison, 1994); Donald Neal Wood, “The First Decade of the 'Fourth' Network: An Historical Descriptive Analysis of the National Educational Television and Radio Center,” (Ph.D. dissertation, The University of Michigan, 1963). 
28. Yeidy M. Rivero, Broadcasting Modernity: Cuban Commercial Television, 1950-1960, (Durham; London: Duke University Press, 2015) and Yeidy M. Rivero, “Havana as a 1940s-1950s Latin American Media Capital,” Critical Studies in Media Communication 26, no. 3 (August 2009): 275-93.

29. Christine Lohmeier, Cuban Americans and the Miami Media, (McFarland \& Company, Inc., Publishers, 2014) and Soruco, Cubans and the Mass Media in South Florida.

30. Soruco, Cubans and the Mass Media in South Florida; and Lohmeier, Cuban Americans and the Miami Media.

31. López, La Radio en Cuba, 332; and Jack E. Anderson, “Latin TV Newsmen Have Captive Viewers," Miami Herald, 16 December 1960, 2-E.

32. Michael Brian Salwen, Radio and Television in Cuba: The Pre-Castro Era, (Ames: Iowa State University Press, 1994), 3-4.

33. García, Havana USA; Lohmeier, Cuban Americans and the Miami Media; Rivero, Broadcasting Modernity; and Salwen, Radio and Television in Cuba.

34. Ibid., 5 .

35. Rivero, Broadcasting Modernity, 35: and Salwen, Radio and Television in Cuba, 8.

36. Salwen, Radio and Television in Cuba, 4-7.

37. Jesús Martín-Barbero et al., Communication, Culture and Hegemony: From the Media to Mediations, (New Delhi London Newbury Park: Sage, 1993); Ana M. López, “Our Welcomed Guests: Telenovela in Latin America," in To Be Continued: Soap Operas around the World, ed. Robert Clyde Allen (New York: Routledge, 1995), 256-75; Rivero, 'Havana as a 1940s-1950s,' 276; and Nora Mazziotti, ed., El Espectáculo de La Pasión, Colección Signos y Cultura 4 (Buenos Aires, Argentina: Ediciones Colihue, 1993).

38. Rivero, Broadcasting Modernity, 35.

39. Rivero, 'Havana as a 1940s-1950s,' 282.

40. Rivero, Broadcasting Modernity, 35; and Salwen, Radio and Television in Cuba, 279.

41. Rivero, 'Havana as a 1940s-1950s,' 276.

42. Ibid., 282; and Jesús Martín-Barbero, "Memory and Form in the Latin American Soap Opera," in To Be Continued: Soap Operas around the World, ed. Robert Clyde Allen (New York: Routledge, 1995), 276-84.

43. Rivero, Broadcasting Modernity, 52 .

44. Ibid., 36.

45. Ibid., 57.

46. Ibid., 71.

47. Barlow, "Rebel Airways," 123-34. 
48. Ibid., 124.

49. Alejandra Bronfman, "Radio Wars and Revolution in the Caribbean, 1959," Journal for Media History 22, no. 2 (December 19, 2019)

50. Rivero, 'Havana as a 1940s-1950s,' 287.

51. Susan D. Greenbaum, More than Black: Afro-Cubans in Tampa (Gainesville: University Press of Florida, 2002). Hoffnung-Garskof, Racial Migrations; Antonio M. López, Unbecoming Blackness: The Diaspora Cultures of Afro-Cuban America. (New York University Press, 2012); and Mirabal, Suspect Freedoms, 2017.

52. Rivero, "Interpreting Cubanness, Americanness, and the Sitcom.'

53. Soruco, Cubans and the Mass Media in South Florida, 34.

54. Lohmeier, Cuban Americans and the Miami Media, 20.

55. García, Havana USA, 106.

56. Ibid., 31; and "Investigation of the Assassination of President John F. Kennedy," 95 ${ }^{\text {th }}$ Congress, second session, Vol. X, March 1979, Congressional Record Archive, 8, 81.

57. Dolores Inés Casillas, Sounds of Belonging: U.S. Spanish-Language Radio and Public Advocacy, (New York; New York University Press, 2014).

58. García, Havana USA, 109.

59. Lohmeier, Cuban Americans and the Miami Media, 73.

60. Jack E. Anderson, “Latin TV Newsmen Have Captive Viewers,” Miami Herald, 16 December 1960, 2-E.

61. Ibid., 2-E. Also see López, La Radio en Cuba, 332. This is not to be confused with famed columnist Jack Anderson, winner of the 1972 Pulitzer Prize for National Reporting.

62. Luisa Yanez, “Emmy-winning Spanish-language News Pioneer Dies,” Miami Herald, 4 January 2008, B1.

63. Mora, Making Hispanic.

64. Yanez, "Emmy-winning Spanish-language News Pioneer Dies,” B1.

65. Anderson, “Latin TV Newsmen Have Captive Viewers," 2-E.

66. “WTVJ-Florida’s First TV Station,” Back Stage, 26 November 1976, 16.

67. Yanez, “Emmy-winning Spanish-language News Pioneer Dies,” B1.

68. “Programming," Television Digest, December 19, 1960, 10; and Oportunidades-orientacion para refugiados, Vol. 3, No. 6, August 1968.

69. Frank Soler, “TV With Latin Flair Going on Air Here Soon,” Miami Herald, 10 March 1969, 12-B.

70. Ibid., 12-B.

71. López, La Radio en Cuba, 367. 
72. Soler, "TV With Latin Flair Going on Air Here Soon."

73. García, Havana USA.

74. Mora, Making Hispanic, 124.

75. Báez, "The Founding of Univision and Spanish-Language Media," 792.

76. Ibid., 795.

77. Mora, Making Hispanic, 132.

78. Ibid., 136.

79. Peter Broderick, “Hispanic Heat Is On,” TV World (May 1987), 86-87.

80. Soruco, Cubans and the Mass Media in South Florida, 47.

81. Mora, Making Hispanic, 144.

82. Sinclair, "The Hollywood of Latin America."

83. Ibid., 222.

84. Mora, Making Hispanic.

85. Báez, "The Founding of Univision”; and America Rodriguez, "Creating an Audience and Remapping a Nation: A Brief History of US Spanish Language Broadcasting 1930-1980," Quarterly Review of Film and Video 16, no. 3-4 (January 1, 1997): 357-74; and Mora, Making Hispanic.

86. Sinclair, "The Hollywood of Latin America,” 211.

87. “Crisis, Amigo Special,” The Miami Herald, December 5, 1961, 18-A.

88. “TV’s ‘Crisis Amigo’: Documentary Flimsy,” The Miami News, December 6, 1961.

89. $87^{\text {th }}$ Congress, Subcommittee to Investigate Problems Connected with Refugees, Second Session, “Cuban Refugee Problem,” Dec. 3-4, 1962; and Public Broadcasting Act of 1967, May 17, 1967, S7013, Congressional Record Archive, United States of America.

90. Jack E. Anderson, “Cuban Refugees Have Their Day on Miami’s TV Lanes,” 15 December 1961, 2-B.

91. Raul Rivero, “Coacciona Castro a Cubanos,” The Miami Herald, 7 December 1961, 33. My translation.

92. 87th Congress, Subcommittee to Investigate Problems Connected with Refugees, “Cuban Refugee Problem.”

93. Ibid.

94. Anderson, “Cuban Refugees Have Their Day,” 2-B.

95. Gerardo Abascal, Notes, 18 December, the Truth About Cuba Committee Records, Box 9, File 3, Cuban Heritage Collection, University of Miami Libraries, Coral Gables, Florida, hereafter TACCR. 
96. Luis Manrara, “Memorandum No.16,” October1961, Luis V. Manrara Papers, Box 34, Folder 2, University of Miami Libraries, Coral Gables, Florida. Hereafter LVMP.

97. Luis Manrara, "Its Motives, Organization and Goals," 22 September 1988, Box 118, Folder 2, p2-3, TACCR.

98. García, Havana USA, 1996, 106.

99. Luis Manrara, Letter to Ralph Renick, 12 September 1967, Box 13, Folder 12, TACCR. The original letter is addressed to 'Senator Pope,' however no such person exists. It is reasonable to believe that Manrara meant "Dodd" since he had contact with him before.

100. Luis Manrara, Letter to Gentlemen, 2 September 1963, Box 6, Folder 6, LVMP.

101. Luis Manrara, Letter to Norman Díaz, 28 August 1969, Box 13, Folder 9, TACCR.

102. Mwakasege-Minaya, "Exiled Counterpoints."

103. Jack Gould, “TV: ‘N. E. T. Journal’ Presents ‘Report From Cuba’, New York Times, 31 Oct 1967, 91.

104. Brooks, "Documentary Programming."

105. Daniel Einstein, Special Edition: A Guide to Network Television Documentary Series and Special News Reports, 1955-1979 (Metuchen, N.J: Scarecrow, 1987).

106. Curtin, Redeeming the Wasteland, 3.

107. Ibid., 2.

108. These figures were put together by going through all of the programs involving Cuba listed in Einstein, Special Edition.

109. Ibid., 227.

110. Ibid., 232, 234.

111. Leonard Ray Teel, Reporting the Revolution.

112. Ibid., 9.

113. Rivero, Broadcasting Modernity, 116; and Einstein, Special Edition, 778.

114. Einstein, Special Edition, 783.

115. Ibid., 320. The first live broadcast from the US to Cuba was in 1954, Yeidy Rivero inform us that this made Cuba the "first country to use an airplane as a relay antenna to transmit a live event (the 1954 World Series of baseball)." See Rivero, Broadcasting Modernity, 8.

116. Einstein, Special Edition, 237.

117. Ibid., 103.

118. Curtin, Redeeming the Wasteland, 83. 
119. Einstein, Special Edition, 164.

120. Ibid., 170, 171, and 220.

121. Ibid., 837.

122. Richard Helms, "Interview with U.S. Newswoman with Fidel Castro Indicating Possible Interest in Rapprochement,” 1 May 1963, National Security Archive, CIA Briefing, Gelman Library, George Washington University.

123. Brooks, "Documentary Programming and the Emergence of the National Educational Television Center as a Network"; Wood, “The First Decade of the "Fourth' Network.”

124. Brooks, "Documentary Programming and the Emergence of the National Educational Television Center as a Network," 1.

125. Laurie Ouellette, Viewers like You? How Public TV Failed the People (New York: Columbia University Press, 2002).

126. Rivero, The Original Miami Sound Machine; Sinclair, “The Hollywood of Latin America;” and Báez, “The Founding of Univision and Spanish-Language Media”.

127. Mwakasege-Minaya, "Cold War Bedfellows.”

\section{Biography}

Richard Mwakasege-Minaya is a Goizueta Foundation Fellow and holds a Ph.D. from the Department of Film, Television, and Media at the University of Michigan. His work can be seen in Historical Journal of Film, Radio and Television; Jump Cut; and Chiricú Journal: Latina/o Literatures, Arts, and Cultures. Mwakasege-Minaya broadly focuses on Latinas/os/xs, the Caribbean, and the media, paying particular attention to the intersections of media industries, activism, and transnationalism. His teaching interests include film and media history and theory, Latina/o/x Studies, and the Caribbean. 


\section{TMG Journal for Media History}

Volume 24 No $(1 / 2) / 2021$

\section{DOI}

https://dx.doi.org/10.18146/tmg.783

\section{PUBLISHER}

Netherlands Institute for Sound and Vision

\section{COPYRIGHT}

Each article is copyrighted (c) by its author(s) and is published under license from the author(s). When a paper is accepted for publication, authors will be requested to agree with the Creative Commons Attribution 4.0 International License. 